\title{
FREIGHT TRAM CONCEPT FOR THE CITY OF POZNAŃ
}

\begin{abstract}
The work presents the concept of a freight tram and examples of trams used in European cities. The concept of a freight tram in Poznan and the Municipal Integrated Logistics Center that manages the delivery of goods to customers has been presented. The use of a freight tram in urban logistics requires from the city carrier a detailed plan for the delivery of cargo from shippers to recipients, in order to eliminate congestion in the tram network. The establishment of the Integrated Logistics Center gives you the opportunity to create a coherent system of goods distribution and transport traffic control in the city. Some selected patterns of transshipment of goods using, among others, railway terminals are presented.
\end{abstract}

Keywords: freight tram, city logistics

\section{Introduction}

Most of contemporary cities are struggling with problems arising from their development, aging infrastructure, population migration and many other factors. Currently, about $50 \%$ of the world's population lives in cities, while according to statistical data by 2030, this share will increase to $60 \%$ and up to 2050 to $70 \%$. With such tendencies one should take into account the growing problems related to the overpopulation of urbanized areas. Another transport problem of cities is the increasingly difficult optimization of both passenger and freight flows in cities.

The increase in the demand for goods in the city results in the increase of the number of vehicles, which means increased congestion, pollution of the urban environment, increase in distribution costs, extension of delivery time, etc. In connection with the increasing problems of urban transport, the introduction of freight 
trams seems to be a good solution because it can offload the roads, reduce exhaust emission and improve many other factors that affect the quality of life in cities ${ }^{1}$.

The city plays an important role in the life of its inhabitants. It provides places of residence, employment and contributes to the growth of economic and cultural activity. However, permanent access to goods and services can be considered the most important function of the city. This requires the creation of a harmonious and efficient transport system. The constantly growing number of inhabitants and, consequently, the growth of mass consumerism causes a rapid development of the city's shopping and service zones. One of the possibilities to solve this problem in cities which have a tram network is to use it for the transport of goods ${ }^{2}$.

\section{The idea of a freight tram in the city}

The use of trams to supply goods to stores located in the city centers allows to eliminate many inconveniences related to transport with the use of trucks. Cities that have a tram network become potential candidates for the introduction of a freight tram. The idea of moving cargoes in the city area using trams is also conducive to a change of views on tram transport, systematically developing since the 1980s. Environmental aspects also play an important role here, a smaller number of cars improve air quality and reduce noise in the city.

The strengths of a freight tram in the city include:

- low noise level - thanks to the electric drive used;

- environmental performance - the tram does not generate virtually any pollution;

- spatial range - track infrastructure allows the entry of a freight tram into the strict center, where road transport has restrictions (parking);

- reduction in the number of vans in favor of freight trams.

The weaknesses of tramway freight are:

- dependency on the tram infrastructure;

- possibility of delays with the schedule;

- high costs of specialized rolling stock;

- blocking lines -during delays of loading and unloading operations.

An indispensable part of plans to introduce rail freight transport in the city is technical conditions. Therefore, it is necessary to analyze all possibilities, limitations and get acquainted with available means that will help in the integration of various modes of transport in order to ensure a smooth flow of goods ${ }^{3}$.

J. Poliński, Rola tramwaju towarowego w ograniczeniu wykorzystywania TIR-ów zaopatrujących duże miasta, Problems of Rail Transport 2008, 146, p. 53-64.

2 I. Dembińska-Cyran, Zastosowanie tramwajów towarowych w obstudze dostaw na obszarze miasta, LogForum Electronic Journal Science Logistyka 2005, 6.

3 K. Lewandowski, Użycie tramwaju towarowego w logistyce miejskiej, Logistyka 2002, 6, p. 63-66. 


\section{Freight trams in Europe}

The beginnings of the use of trams for transporting cargo date back to the turn of the $19^{\text {th }}$ and $20^{\text {th }}$ centuries. The first attempts were made in the times when wagons pulled by horses left the tracks. However, the small animal train capacity significantly reduced both the speed of transport and the maximum load capacity. The solution to transport problems has become the use of electric trams.

At the beginning of the $20^{\text {th }}$ century, there were mainly two types of tram carriages in Europe. The first one were electric vehicles, covered by self-propelled vehicles, mainly rebuilt from passenger trams (removal from the interior of seats). The second group consisted of trailer wagons. Most often, these were remodeled coalmines and platforms.

In Poland, freight tram transport services functioned in almost every city with a more extensive network of railways. In 1917, the transport of postal items was launched in Poznań. Szczecin started the operation of post trams two years later than Poznań, in 1919. The last example of a city with trams was Wrocław. The system was launched in $1921^{4}$.

The increase in the importance of freight trams took place with the outbreak of World War II due to the rationing of fuel and requisitioning trucks and passenger cars for the purposes of military operations. In the German-occupied city, trams were used to transport ammunition or to export slave-labor products from the Jewish population.

After World War II, freight trams were used to debris Polish cities. Figure 1 shows a tram set (tram and railway carriages) for the removal of debris from damaged Wrocław.

Nowadays, trams are used to a small extent for transporting cargo. They are mainly used in municipal transport companies as trams for transporting mechanical parts between depots. However, there is hope that the goods will be relocated to the rails thanks to several western cities implementing modern tramway projects.

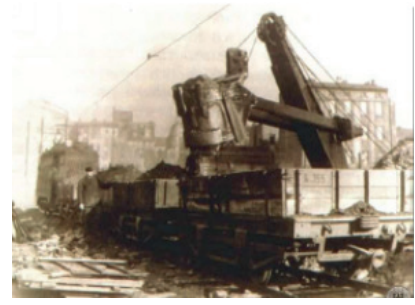

Figure 1. Removal of debris from Wroclaw after the war

Source: http://wroclaw.hydral.com.pl/64189,foto.html (access: 2.04.2010)

Dresden is currently one of the few cities in the world where trams are used to transport goods. The idea of introducing a freight tram to the streets of the city gave rise to the late ' 90 s of the twentieth century with the idea of building a VW "transparent car factory" by VW. The factory called "Glass Manufactory" was to be

4 M. Zych, K. Lewandowski, Tramwaje towarowe na świecie i w Polsce, Logistyka 2015, 4, p. 3828-3835. 
available for passers-by, that is, that they could observe the VW car construction process from the street. The production plant was built at Straßburger Platz. This location is not accidental. Investors wanted the factory to be located near the city center ${ }^{5}$.

It was decided to build the main part warehouse, being at the same time the logistic center of the new factory, to build outside the city center of Dresden and arrange delivery of parts of the cars to the factory with special trams. Trunk sidings were built at the factory and logistics center. They were connected to the municipal tram network. The production plant also gained a terminal enabling loading and unloading of containers with parts from the tram, as shown in Figure 2.

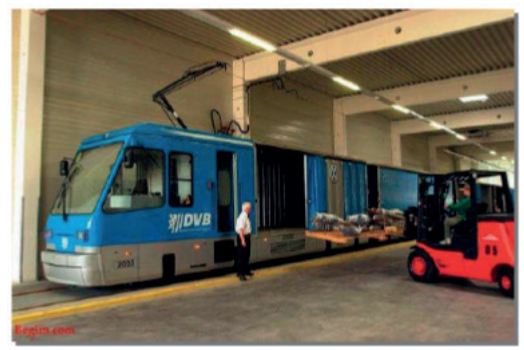

Figure 2. Unloading terminal at the VW factory in Dresden

Source: http://www.begim.com/ext/funvideos/interestinglinks/VolksWagen/Cargo_Tram.jpg (access: 3.03.2018)

The city of Zürich, following the example of Dresden, decided to use trams to transport freight. This idea is not a new thing in the city. Between 1898 and 1966, various goods were transported by trams. From 1898, urban rail transport was used to move mail. The Cargotram project was developed jointly by the Department of Municipal Transport VBZ and the Waste Disposal and Recycling Facility. Special points have been designated in the city where residents can bring waste. Along with the growing transport demand, the Cargotram offer was extended in 2006 with the E-tram, i.e. the tram collecting the so-called Electro. Figure 3 shows a goods trolley for collecting and transporting waste ${ }^{6}$.

Amsterdam is the next city after Dresden and Zurich, where it was planned to launch a freight tram. The idea of introducing this fairly innovative form of urban transport of goods was initiated in 2004. The tram infrastructure of Amsterdam was used to distribute the goods. Special distribution centers called Cross Docks have been designed. Figure 4 shows the built-in city tram in Amsterdam. Despite numerous awards received by the City Cargo project, a lot of support and interest, successful tests and bold plans for the future, it has not been realized ${ }^{7}$.

5 http://www.begim.com/ext/funvideos/interestinglinks/VolksWagen/Cargo_ Tram.jpg (access: 3.03.2018).

6 http://upload.wikimedia.org/wikipedia/commons/2/27/Cargo_Tram_outside_Zurich_Hauptbahnhof. JPG (access: 3.03.2018).

7 http://tram-2.andreetjes-website.nl/cargo_tram_amsterdam/citycargo_801_1_akp.jpg (access: 3.03.2018). 


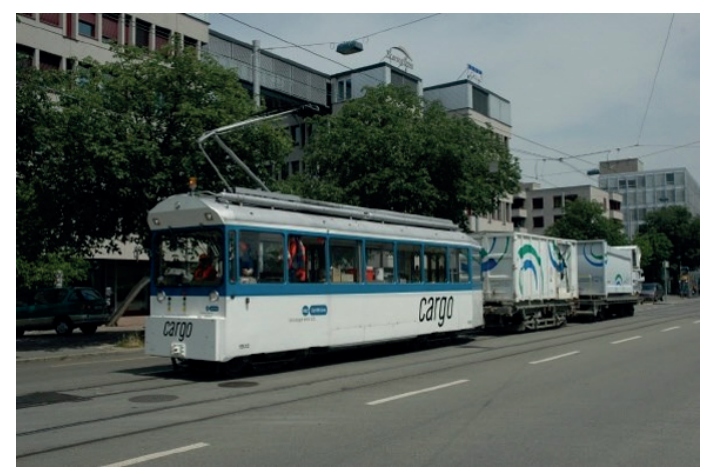

Figure 3. A freight tram in Zürich in the colors of the VBZ carrier Source: http://upload.wikimedia.org/wikipedia/commons/2/27/Cargo_Tram_outside_Zurich_Hauptbahnhof.JPG (access: 4.03.2018)

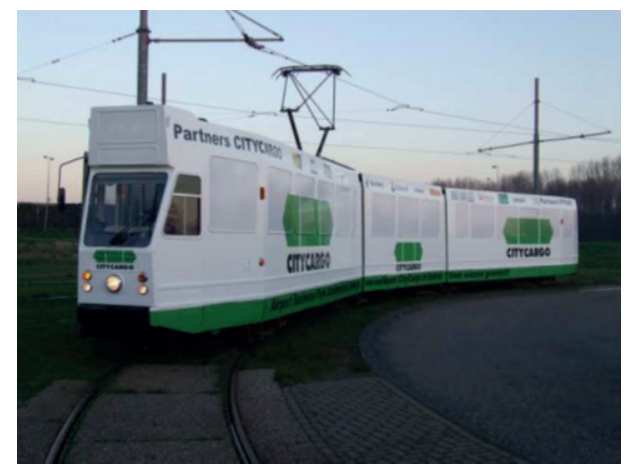

Figure 4. A freight tram in Amsterdam City Cargo VBZ

Source: http://tram-2.andreetjes-website.nl/cargo_tram_amsterdam/citycargo_801_1_akp.jpg (access: 4.03.2018)

The Güterbim project in Vienna is the latest solution for the use of trams to transport loads in the city. The basis for starting the work was the resolution of the Vienna City Council taken in August 2004. It concerned the introduction of freight transport throughout the urban rail infrastructure. The Güterbim concept was part of the F \& E I2 "Intelligent Infrastructure" program of the Ministry of Communications, Innovation and Technology. The plans for launching a freight tram were jointly developed by Urban Transport Company (Wiener Linien), Vienna Local Railways (Wiener Lokalbahnen), TINA Vienna-Transport Strategies GmbH and Vienna Consult Verkehrsberatungsgesellschaft mbH. Figure 5 shows a freight tram in Vienna made for the Güterbi project ${ }^{8}$.

8 http://www.mp-video.at/Video/VIDEOS/Guebi.jpg (access: 4.03.2018). 


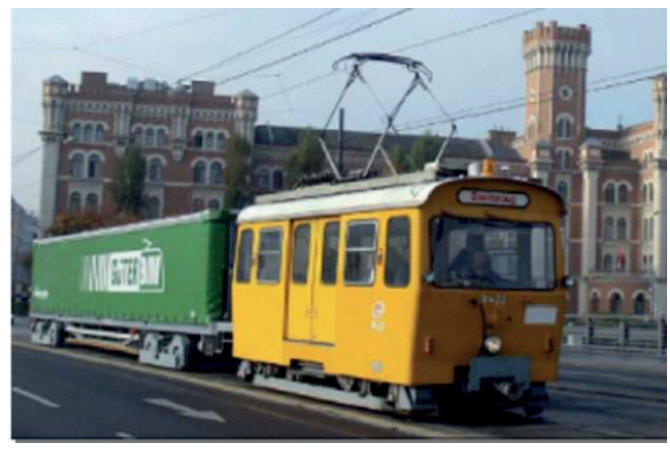

Figure 5. A freight tram used in the Güterbi project

Source: http://www.mp-video.at/Video/VIDEOS/Guebi.jpg (access: 4.03.2018)

The launch of the freight tram in Dresden in 2001 and the numerous economic and environmental benefits resulting from this fact for the city contributed to the increase of interest in this ecological form of transport. Many cities use this form of freight transport, which is probably the only alternative to crowded cities.

\section{The concept of a freight tram in Poznan}

Poznan is one of the fifteen cities in Poland with an extensive tram network. Periodically enlarged since its inception, it covers all five districts of the city: Grunwald, Wilda, Jeżyce, Stare Miasto and Nowe Miasto. Four depots and one square of holding tracks are located within the system. The total length of individual tracks is about $157.7 \mathrm{~km}$, of which nearly $140 \mathrm{~km}$ are track lanes. Tram routes are terminated with 14 loops. The largest grouping of tracks is located in the city center. Almost $3 / 4$ of the entire network consists of traffic rails separated from traffic, allowing trams to efficiently travel during rush hours. There are over 20 daily tram lines in Poznań. The manager of the rail transport infrastructure is Urban transport company.

The delivery system in the city could be based on the use of a logistics center acting as an operational base from where freight trams would deliver cargo directly to recipients or selected points on the tram network, and could then be transported, for example, by electric cars. An important element of the whole system would be the Urban Integrated Logistics Center (MZCL), whose main goal would be to manage tramway transport in Poznań.

The proposed location is the area in the vicinity of the newly created tram depot between the production plants of the Lech beer company and the M1 shopping center (Figure 6). The location of the Urban Integrated Logistics Center in this area is not accidental. The space on Franów is mainly used by production plants and supermarket chains, which would allow for quick acquisition of suppliers and potential recipients of goods. This depot would provide a stopping place for freight trams as well as adequate facilities and technical support 9 .

9 P. Kuczyński, Tramwajowy transport towarów w aglomeracji miejskiej Poznania, Diploma thesis, Poznań 2010. 


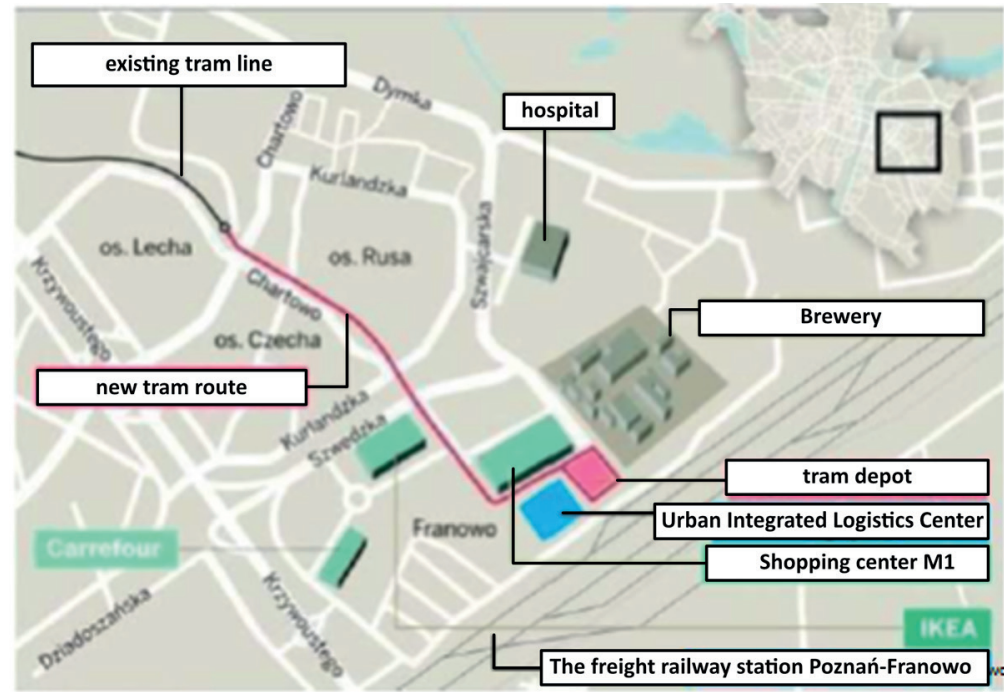

Figure 6. Location of the Municipal Integrated Logistics Center in Franowo

Source: P. Kuczyński, Tramwajowy transport towarów w aglomeracji miejskiej Poznania, Diploma thesis, Poznań 2010

A very important argument in favor of the location of the center on Franowo is the railway lines running through this area and very important for the national road transport. There is a large freight station in the area where trains with cargo throughout the country are formed daily from around 3500 wagons.

Important advantages of Poznań are the numerous points located in its area, which could be adapted in the project of a freight tram. Of course, this involves a lot of financial effort to adapt such locations to design expectations. These places include:

- tram loops;

- so-called "dead tracks" - places where there are tram tracks not used for years or used sporadically;

- potentially strategic places for the development of the concept of a freight tram. The following is an example of the use of tram loops as potential terminals for transshipment of goods.

Górczyn - a tram loop in the south-western part of Poznań in the immediate vicinity of the Poznań - Górczyn station and a line leading to Berlin and Western Europe (Figure 7). The distance between tram and railway tracks is only about 70 meters. This place is suitable for organizing a terminal for reloading goods from railway wagons to a tram. For this purpose, the so-called closed "Staroberlinski Trails" located east of the Górczyński viaduct. Bringing the tram track to the "Staroberlinski Tracks" and building a transshipment point there would create new prospects for many institutions nearby. 


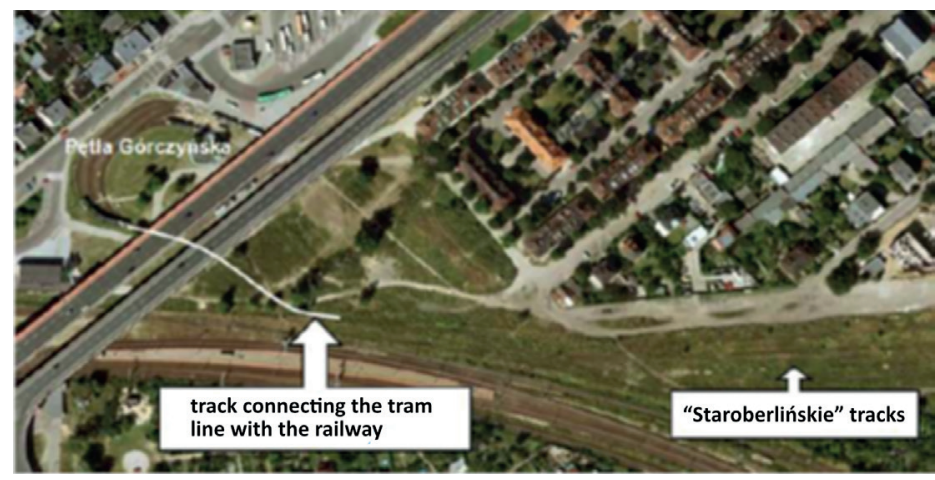

Figure 7. The proposed connection of the tramway loop on Górczyn with railway tracks

Source: P. Kuczyński, Tramwajowy transport towarów w aglomeracji miejskiej Poznania, Diploma thesis, Poznań 2010

Dębiec - location: the southern part of Poznan. There is a tram loop there, it borders with railway tracks, as shown in Figure 8. The disadvantage of this place is a small area of the Dębbie loop itself, therefore, due to the limited space, an important solution would be to "plug in" one tram track to the railway line near Poznań - Dębiec. Such an undertaking would allow not only to launch freight transport, but also to connect the rail passenger traffic with the urban traffic.

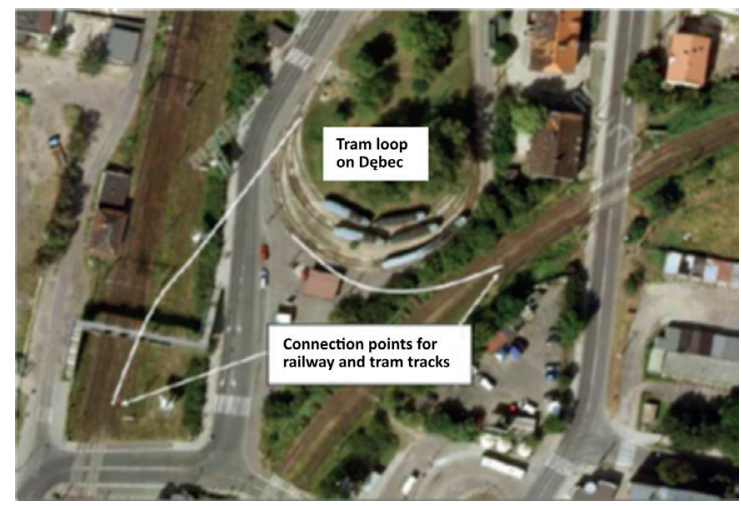

Figure 8. Possible variants of connecting the tram terminal in Dębec with the railway node Source: P. Kuczyński, Tramwajowy transport towarów w aglomeracji miejskiej Poznania, Diploma thesis, Poznań 2010

Starołęa - south-eastern part of the city. The tram terminal is located next to the depot on Forteczna street, which has a direct connection to the railway tracks (Figure 9). The connecting track has been unused for several years. It could be used as a place where two-system freight trams would enter the railway tracks. Next to the depot at the Poznan - Starołęka railway station there is a closed ramp and railway sidings. With a small financial outlay, this place could be adapted to reload goods from railway wagons to freight trams. 


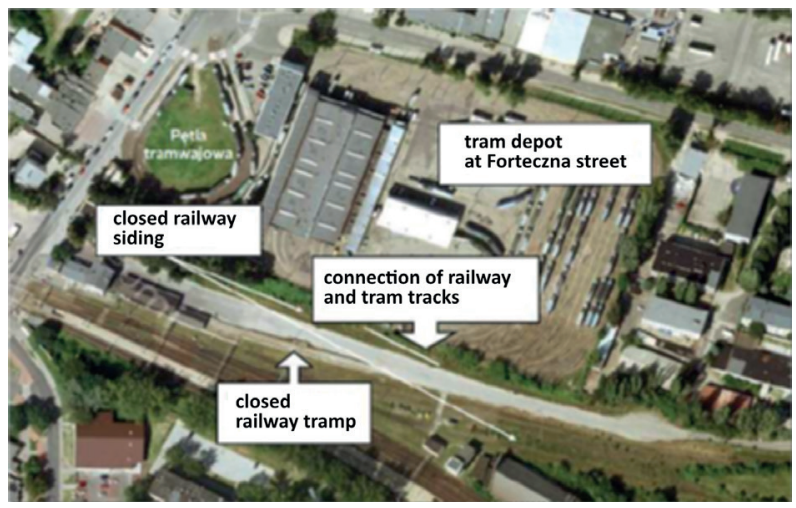

Figure 9. Tram depot at Forteczna street and unused railway sidings

Source: P. Kuczyński, Tramwajowy transport towarów w aglomeracji miejskiej Poznania, Diploma thesis, Poznań 2010

\section{Conclusions}

The paper presents issues related to the transport of freight inside urban agglomerations with the indication of freight trams, as an alternative logistic solution to the supply problems of cities, related to the constantly growing number of cars affecting the creation of the congestion problem.

The development of the idea of transporting goods by trams can be a solution to the supply problems of many cities. High payload (replacing sometimes four semi-trailers) and spatial coverage make the freight tram a vehicle that can contribute to a significant reduction in the number of vans and trucks, thereby reducing the risks associated with improper parking and blocking streets and reducing congestion. Due to the type of drive (electric motors), the tram does not emit any fumes and generates much less noise than internal combustion engines, which makes it an environmentally friendly vehicle.

The introduction of freight trams in the city is an extremely complicated task. There are many legal and technical issues to be solved when creating a project. Efficient operation of this type of transport requires a lot of involvement of both authorities and entrepreneurs.

\section{References}

Dembińska-Cyran I., Zastosowanie tramwajów towarowych w obstudze dostaw na obszarze miasta, LogForum - Electronic Journal Science Logistics 2005, 6.

http://www.begim.com/ext/funvideos/interestinglinks/VolksWagen/Cargo_Tram.jpg (access: 3.03.2018).

http://tram-2.andreetjes-website.nl/cargo_tram_amsterdam/ citycargo_801_1_akp.jpg (access: 3.03.2018).

http://upload.wikimedia.org/wikipedia/commons/2/27/Cargo_Tram_outside_Zurich_Hauptbahnhof.JPG (access: March 2018). 
http://wroclaw.hydral.com.pl/64189,foto.html (access: 2.04.2010).

http://www.mp-video.at/Video/VIDEOS/Guebi.jpg (access: March 2018).

Kuczyński P., Tramwajowy transport towarów w aglomeracji miejskiej Poznania, Diploma thesis, Poznań 2010.

Lewandowski K., Użycie tramwaju towarowego w logistyce miejskiej, Logistics Magazine 2002, 6. Poliński J., Rola tramwaju towarowego w ograniczeniu wykorzystywania TIR-ów zaopatrujących duże miasta, Problems of Rail Transport 2008, 146.

Zych M., Lewandowski K., Tramwaje towarowe na świecie i w Polsce, Logistyka 2015, 4.

\section{Corresponding authors}

Małgorzata Orczyk can be contacted at: malgorzata.orczyk@put.poznan.pl Franciszek Tomaszewski can be contacted at: franciszek.tomaszewski@put.poznan.pl 